\title{
First record of partial erythrism in a species of poison- dart frog of the family Dendrobatidae: Mindo Poison Frog Epipedobates darwinwallacei Cisneros-Heredia and Yánez- Muñoz, 2010
}

\author{
Pedro Peñaherrera-R. ${ }^{1,2 *}$, Andrés Pinos-Sánchez ${ }^{1,2}$ \\ 1 Colegio de Ciencias Biológicas y Ambientales COCIBA, Universidad San Francisco de Quito USFQ, \\ Quito 170901, Ecuador \\ ${ }^{2}$ Museo de Zoología \& Laboratorio de Zoología Terrestre, Instituto iBIOTROP, Universidad San \\ Francisco de Quito USFQ, Quito, Ecuador \\ *Autor para correspondencia / Corresponding author: pedropjpr5380@gmail.com
}

\section{Primer registro de eritrismo parcial en una especie de rana venenosa de la familia Dendrobatidae: Epipedobates darwinwallacei Cisneros-Heredia y Yánez-Muñoz, 2010}

\section{Abstract}

We report the first recorded case of partial erythrism in a frog belonging to the family Dendrobatidae, the Mindo Poison Frog Epipedobates darwinwallacei Cisneros-Heredia and Yánez-Muñoz, 2010. In February 2019, we found an individual in the valley of Mindo, province of Pichincha, Ecuador, showing dorsal surfaces uniformly orange, throat and posterior surfaces of legs black, and ventral surfaces yellow. Despite the atypic colouration, its external morphology coincides with E. darwinwallacei, and individuals with typical colouration for the species were abundant syntopically. We include photographs comparing the erythristic individual and a typical colouration frog from the same area. We provide a brief review of chromatic atypic colourations reported in Dendrobatoidea.

Keywords: Atypical colouration, Anura, Dendrobatoidea, Chromatic anomaly

\section{Resumen}

Reportamos el primer caso de eritrismo parcial para la familia Dendrobatidae; Epipedobates darwinwallacei Cisneros-Heredia y Yánez-Muñoz, 2010, encontrado en el valle de Mindo, 2019, provincia de Pichincha, Ecuador. Este individuo presenta una coloración anaranjada uniforme en el dorso, garganta y superficies posteriores de las piernas negras, y superficies ventrales amarillas. A pesar de presentar una coloración atípica, su morfología externa coincide con la de E. darwinwallacei, e individuos con la coloración típica fueron abundantes en sintopía. Incluimos un breve resumen de los reportes de coloración cromática atípica de Dendrobatoidea y evidencia fotográfica comparando el individuo con eritrismo y uno con coloración normal de la misma localidad.

Aceptado / Accepted: 08/10/2021

Publicado en línea / Published online: $15 / 12 / 2021$ 
First record of partial erythrism in a species of poison-dart frog of the family Dendrobatidae: Mindo Poison Frog Epipedobates darwinwallacei Cisneros-Heredia and Yánez-Muñoz, 2010 Peñaherrera-R/ Pinos-Sánchez (2021)

One of the families with the highest rate of variation in aposematic colouration is Dendrobatidae [1]. Variation in colours and patterns in dendrobatids is usually related to warning visually oriented predators of their potential toxicity [1]. Even within populations of Dendrobatidae species, variation rates are high on colour hue and pattern. Myers \& Daly [2][3] and Brown and collaborators [4] remarked that intrapopulation variation in Dendrobatidae is strongly impacted by geographic distribution and migration. Mutations and atypical colourations could occur more frequently due to the exchange of genetic information from different geographical lineages as a result of migration [2-3]. Studies in Oophaga pumilio have evidenced that genetic drift may impact the expression of new colour phenotypes [4].

Different colouration anomalies have been reported in anurans, such as melanism, albinism and leucism [5]. Selective expression of pigments not related with these three anomalies previously mentioned are even more rare to see in wild populations (e.g., xanthism, erythrism, and axanthism) [6][7]. Unlike the variation in the colour pattern, which is caused by environmental pressures (e.g., visually oriented predators, body size and camouflage on heterogeneous backgrounds) over the fitness of individuals that forces more variable phenotypes, it is suggested that the expression and loss of specific pigmentations associate with morphological conditions, random mutations and immunological abnormalities [1][5][8-11].

Epipedobates is a genus of poison-dart frogs of the family Dendrobatidae with seven species in northern South America [12]. Mindo Poison Frog Epipedobates darwinwallacei Cisneros-Heredia and Yánez-Muñoz, 2010 is endemic to cloud forests on the Cordillera Occidental of the Andes in north-western Ecuador, at an altitude between 1250 and 1390 m.a.s.l. This species inhabits near swamps and slow streams in primary and secondary forests [13-15]. E. darwinwallacei is a small frog characterised by having a black to dark brown dorsum with orange to bright yellow spots, pale yellow oblique longitudinal lateral stripe on flanks, dark throat and dark venter with large orange or yellow spots [13-15].

Several colouration anomalies have been reported in wild populations of Dendrobatoidea, including partial leucism in Epipedobates anthonyi [16], partial leucism in Allobates femoralis [5], leucism in Dendrobates truncatus [17], partial leucism in Anomaloglossus stepheni [18], albinism in froglets and tadpoles of Mannophryne trinitatis [19], and creamy pigmented eggs and tadpoles of D. auratus [20]. All reported cases are related to the expression of iridophores and melanophores. Herein, we present the first report of partial erythrism in a species from Dendrobatidae. Erythrism is the overexpression of xanthophores that provide yellow-orange and red-orange hues due to carotenoid and pteridine pigments [7]. 


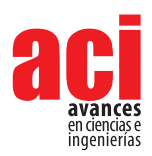

First record of partial erythrism in a species of poison-dart frog of the family Dendrobatidae: Mindo Poison Frog Epipedobates darwinwallacei Cisneros-Heredia and Yánez-Muñoz, 2010 Peñaherrera-R/ Pinos-Sánchez (2021)

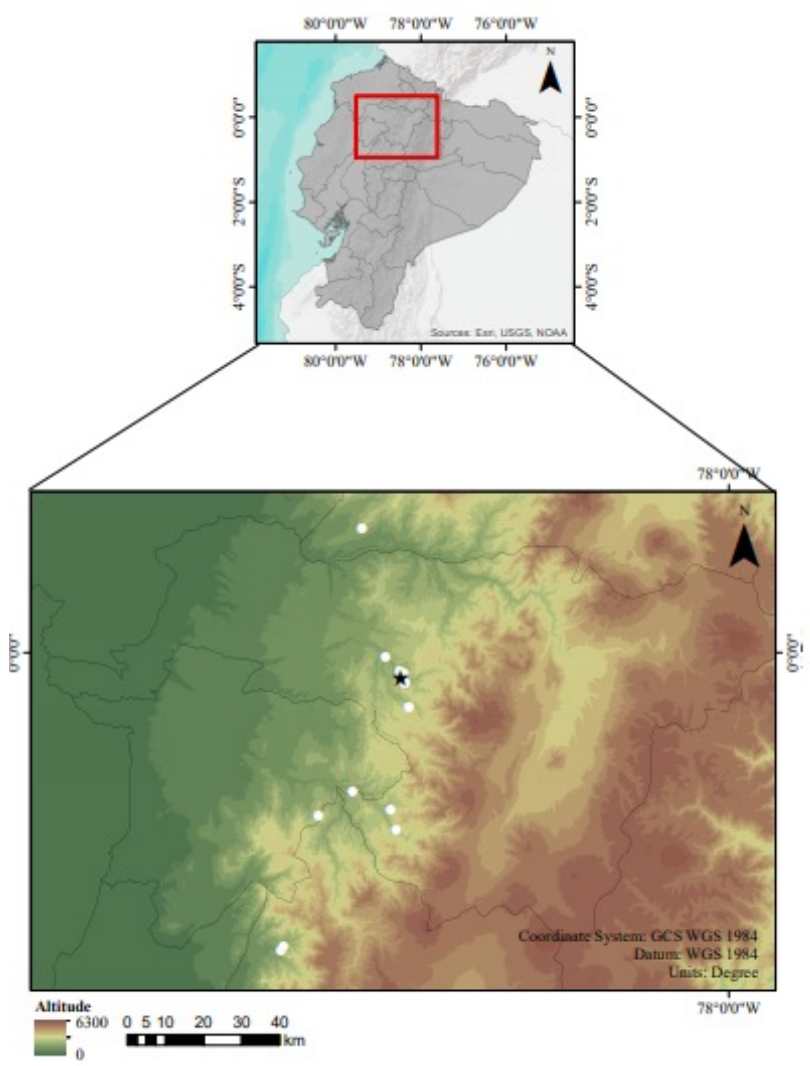

FIGURE 1: Occurrences (white spots) of E. darwinwallacei and locality (black star) where the partial erythristic individual of E. darwinwallacei was found in the valley of Mindo, province of Pichincha, Ecuador.

During an expedition in February 2019, an adult male with partial erythrism (unvouchered specimen) identified as Epipedobates darwinwallacei by its straight and weakly curved tarsal keel [13] was found next to a temporary creek in a ravine near the River Mindo, province of Pichincha, Ecuador (0.059713 S, 78.774013 W, 1288 m.a.s.l.), active at 22:00 p.m. (Fig. 1). The erythristic individual shows a uniformly dark orange colouration in the dorsal and yellow ventral surfaces (Fig. 2). Flanks are dark orange with a yellow oblique stripe and a black tympanic membrane. Axilla and folds from posterior and anterior legs are black. It still has a dark throat with a yellow spot near the mouth (Fig. 2 D). It does not present the common dorsal pattern of the species_-reticulated, uniformly dispersed spots and medial line forms [13] — nor the ventral mottled pattern that is generally present in most species of Dendrobatidae. The erythristic dorsal pattern and colouration are similar to the uniform brown to reddish-brown dorsal colouration presented by some populations of E. boulengeri [21], a species not found in sympatry. Possibly, this similarity shows that the colour pattern of these two species could be regulated by the same genes, which mutated in the case of the erythristic E. darwinwallacei. 
First record of partial erythrism in a species of poison-dart frog of the family Dendrobatidae: Mindo Poison Frog Epipedobates darwinwallacei Cisneros-Heredia and Yánez-Muñoz, 2010 aci avances en ciencias e
ingenierías

Compared to the size range of adult males' snout-vent length (SVL) $16.5-18.0 \mathrm{~mm}$ of $E$. darwinwallacei [14], the partial erythristic individual SVL measures $19.2 \mathrm{~mm}$. Thus, it is larger than males of E. darwinwallacei and closer to the higher limit size of females (SVL: 13.0-19.5 mm) [15]. This type of chromatic anomaly may be related to growth factors present at the larval stage. Cabrera-Guzmán and collaborators [22] suggested that growth factors could be related to a higher pigment concentration diet, the presence of metals and nutrient sources. For example, some authors have hypothesized that high iron concentrations could be associated with the saturated pigmentation in erythristic Pelobates fuscus [23][24]. Tadpoles developing on high iron concentrations media could produce negative developmental, morphological, genetic and biochemical effects during its development [22]. More reports of chromatic abnormalities in Dendrobatoidea are needed in order to use them as background information for developing extensive research that relates predation and environment over the survival and fitness of these atypically coloured individuals in wild populations.

A

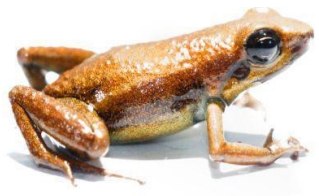

B

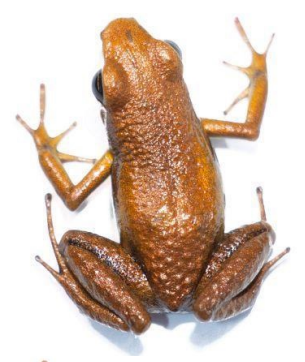

C

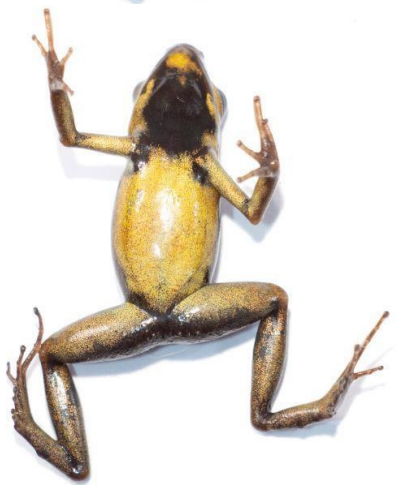

D
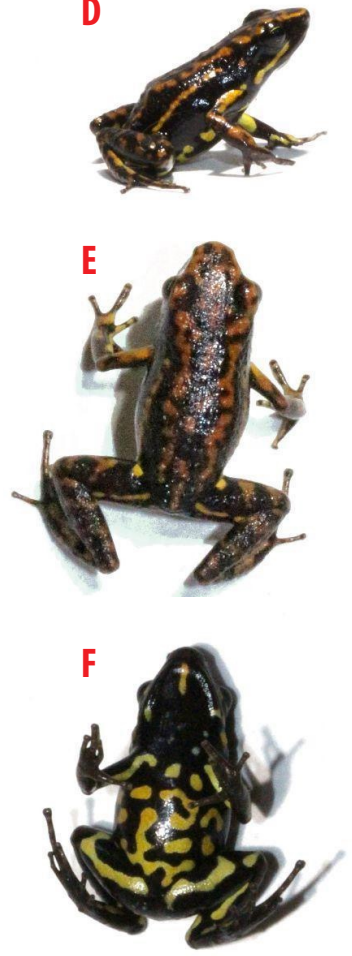

FIGURE 2. Photographs of erythristic (A-C) and typical colouration in Epipedobates darwinwallacei (unvouchered specimen): (A) Dorsolateral, (B) dorsal and (C) ventral views of erythristic individual (SVL: $19.2 \mathrm{~mm}$ ); (D) Dorsolateral, (E) dorsal and (F) ventral views of individual (unvouchered specimen) with typical colouration (SVL: $16.5 \mathrm{~mm})$. Photographs by Pedro Peñaherrera- $R$. 


\section{ACKNOWLEDGEMENTS}

We thank Diego Cisneros-Heredia for his unwavering support and commentaries while we wrote this article; Emilia Peñaherrera-Romero for helping us create Figure 1; members of Universidad San Francisco de Quito USFQ, BBIOTROP institute, Museo de Zoología USFQ and Laboratorio de Zoología Terrestre for their support, guidance and access to lab facilities; and Ana Paula Vásconez, Martina Bautista, Jose Granizo and Ariel Guerrero who participated in the fieldwork carried out in 2019.

\section{AUTHORS' CONTRIBUTIONS}

Writing of the manuscript: Pedro Peñaherrera-R. and Andrés Pinos-Sánchez Production of figures: Pedro Peñaherrera-R.

Analysis and interpretation of data from field work: Pedro Peñaherrera-R. Supervision: Pedro Peñaherrera-R.

\section{CONFLICTS OF INTEREST}

Both authors declare that they have no conflicts of interest. 
First record of partial erythrism in a species of poison-dart frog of the family Dendrobatidae: Mindo Poison Frog Epipedobates darwinwallacei Cisneros-Heredia and Yánez-Muñoz, 2010

\section{aci Brifrences}

[1] Barnett, J. B., Michalis, C., Scott-Samuel, N. E., \& Cuthill, I. C. (2018). Distance-dependent defensive coloration in the poison frog Dendrobates tinctorius, Dendrobatidae. Proceedings of the National Academy of Sciences, 115(25), 64166421. doi: https://doi.org/10.1073/pnas.1800826115

[2] Myers, C. W., \& Daly, J.W. (1976). Preliminary evaluation of skin toxins and vocalizations in taxonomic and evolutionary studies of poison-dart frogs (Dendrobatidae). Bulletin of the AMNH, 157(2), 173-262. Retrieved from http://hdl. handle.net/2246/622

[3] Myers, C. W., \& Daly, J. W, (1983). Dart-poison frogs. Scientific American, 248(2), 120-133. https://www.jstor.org/ stable/24968834

[4] Brown, J.L., Maan, M.E., Cummings, M.E. and Summers, K. (2010), Evidence for selection on coloration in a Panamanian poison frog: a coalescent-based approach. Journal of Biogeography, 37, 891-901. doi: https://doi.org/10.1111/j.13652699.2009.02260.x

[5] Tavares-Pinheiro, R., Costa-Campos, C. E., \& Kaefer, I. L. (2020). A leucistic brilliant-thighed poison frog Allobates femoralis (Dendrobatoidea). Herpetology Notes, 13, 321-323.

[6] Sanabria, E. A., Quiroga, L. B., \& Laspiur, A. (2010). First record of partial albinism and scoliosis in Odontophrynus occidentalis tadpoles (Anura: Cycloramphidae). Brazilian Archives of Biology and Technology, 53(3), 641-642. doi: https://doi.org/10.1590/S1516-89132010000300019

[7] Rivera, X., Arribas, 0., Martí, F. (2001). Revisión de anomalías pigmentarias en los anfibios de la península lbérica y de Europa. Bulletí de la Societat Catalana d'Herpetología, 15, 59-75.

[8] Hagman, M., \& Forsman, A. (2003). Correlated evolution of conspicuous coloration and body size in poison frogs (Dendrobatidae). Evolution, 57(12), 2904-2910. doi: https://doi.org/10.1111/j.0014-3820.2003.tb01531.x

[9] Espanha, J., Vasconcelos, M., \& Eterovick, P. (2016). The role of tadpole coloration against visually oriented predators. Behavioral Ecology and Sociobiology, 70, 255-267. doi: https://doi.org/10.1007/s00265-015-2044-4

[10] Kang, C., Kim, Y. E., \& Yikweon, J. (2016). Colour and pattern change against visually heterogeneous backgrounds in the tree frog Hyla japonica. Scientific Reports, 6, 22601. doi: https://doi.org/10.1038/srep22601

[11] Bókony, V., Verebélyi, V., Ujhegyi, N., Mikó, Z., Nemesházi, E., Szederkényi, M., Orf, S., Vitányi, E., \& Móricz, Á. M. (2020). Effects of two little-studied environmental pollutants on early development in anurans. Environmental Pollution, 260, 114078. doi: https://doi.org/10.1016/j.envpol.2020.114078

[12] Grant, T., Frost, D. R., Caldwell, J. P., Gagliardo, R., Haddad, C. F. B., Kok, P. J. R., Means, D. B., Noonan, B. P., Schargel, W. E., \&Wheeler, W. C. (2006). Phylogenetic systematics of dart-poison frogs and their relatives (Amphibia: Athesphatanura: Dendrobatidae). Bulletin of the American Museum of Natural History, 299, 1-262. doi: https://doi.org/10.1206/00030090(2006)299[1:PSODFA]2.0.C0;2

[13] Cisneros-Heredia, D. F., \& Yánez-Muñoz, M. H. (2010). Una nueva rana venenosa del género Epipedobates (Dendrobatoidea: Dendrobatidae) desde los Andes del noroeste de Ecuador. ACI Avances En Ciencias EIngenierías, 2(3). doi: https://doi.org/10.18272/aci.v2i3.49

[14] Cisneros-Heredia, D. F. (2016) Mindo Poison frog Epipedobates darwinwallacei Cisneros-Heredia and Yánez-Muñoz 2011. In: Kahn, T.R., La Marca, E., Lötters, S., Brown, J. L., Towmey, E., Amézquita, A. Aposematic Poison Frogs (Dendrobatidae) of the Andean Countries: Bolivia, Colombia, Ecuador, Perú and Venezuela. Arlington, Conservation International Tropical Field Guide Series.

[15] Ron, S. R., Merino-Viteri, \& A. Ortiz, D. A. (2019). Anfibios del Ecuador. Versión 2019.0. Museo de Zoología, Pontificia Universidad Católica del Ecuador. Retrieved May 12, 2021, from: https://bioweb.bio/faunaweb/amphibiaweb el 02/05/2020

[16] Brito-Zapata, D. (2021). First report of partial leucism in the poison frog Epipedobates anthonyi (Anura: Dendrobatidae) in El Oro, Ecuador. Neotropical Biodiversity, 7(1), 1-4. doi: https://doi.org/10.1080/23766808.2020.1870256

[17] Rivera-Prieto, D. A., \& Marín-C, D. (2017). Atypical coloration in the yellow-striped poisonous frog, Dendrobates truncatus (Cope, 1861), in the Colombian Magdalena river valley. Cuadernos de Herpetología, 31(1), 33-35. 
[18] Moraes, L.J.C.L., Kaefer, I.I. (2015). Leucism in the Amazonian diurnal frog Anomalogrossus stepheni (Martins, 1989) (Anura: Aromobatiade). Herpetology Notes, 8, 179-181.

[19] Jowers, M. J., \& Downie, J. R. (2004). Distribution of the frog Mannophryne trinitatis (Anura: Dendrobatidae) in Trinidad, West Indies. Living World, Journal of the Trinidad and Tobago Field Naturalists' Club, 2004, 17-19.

[20] Flores, E. E., Moore, A. J., \& Blount, J. D. (2012). Unusual whitish eggs in the poison frog Dendrobates auratus Girard, 1855. Tropical Zoology, 25(2), 67-73. doi: https://doi.org/10.1080/03946975.2012.696401

[21] Cisneros-Heredia, D. F. \& Kahn, T. R.(2016) Marbled Poison Frog Epipedobates boulengeri Barbour 1909. In: Kahn, T.R., La Marca, E., Lötters, S., Brown, J. L., Towmey, E., Amézquita, A. Aposematic poison frogs (Dendrobatidae) of the Andean countries: Bolivia, Colombia, Ecuador, Perú and Venezuela. Arlington, Conservation International Tropical Field Guide Series.

[22] Cabrera-Guzmán, E., Díaz-Paniagua, C., \& Gomez-Mestre, I. (2020). Differential effect of natural and pigmentsupplemented diets on larval development and phenotype of anurans. Journal of Zoology. doi: https://doi. org/10.1111/jzo.12827

[23] Kolenda, K., B. Najbar, A. Najbar, P. Kaczmarek, M. Kaczmarski, and T. Skawiński. (2017). Rare colour aberrations and anomalies of amphibians and reptiles from Poland. Herpetology Notes, 10, 103-109.

[24] McAlpine, D. F., \& Gilhen, J. (2018). Erythrism in Spring Peeper (Pseudacris crucifer) in Maritime Canada. The Canadian Field-Naturalist, 132(1), 43-45. doi: https://doi.org/10.22621/cfn.v132i4.2012 